\title{
Practical recommendations for implementing the project funding mechanism in the transport construction
}

\author{
$\operatorname{Vera} A$. Kudryavtseva ${ }^{1, *}$ \\ ${ }^{1}$ Irkutsk State Transport University, 15, Chernyshevskogo str., Irkutsk, Russia
}

\begin{abstract}
Changes in the Russian and global economies have been affecting all sectors. Neither the transport industry nor the construction one is an exception. These industries are budget-forming, and all participants in business processes should be interested in their strategic development. In order for the federal projects developed by the Ministry of Transport to be effective, a new project funding approach is required. Industries and companies have limited financial resources. The Russian Railways company is no exception due to its limited budgetary funds and own financial capabilities. It is necessary to develop effective mechanisms for funding railway infrastructure projects. Project funding mechanisms can be innovative ways of funding large-scale infrastructure projects, since they are based on a combination of banking, commercial and public resources. Project funding can unite financial resources and competences of project participants. In addition, qualified financial institutions will be involved in project funding transactions, which ensures the timely project implantation. Project funding mechanisms allow for a comprehensive project assessment, since the lender confirms the economic feasibility of the project. Project effectiveness evaluation has become relevant after the adoption of a strategy for the development of railway transport in the Russian Federation until 2030. Polygon technologies are promising for Russian Railways and used by the Trans-Siberian Railways.
\end{abstract}

Keywords: infrastructure, funding, project, investment, budget

\section{Introduction}

The economic and social development of Russia is at the stage of deep transformations. It is important to develop a model that would strengthen the world position of the country. These measures were declared by the President of the Russian Federation. They are aimed at creating a "smart economy" that would contribute to the advanced development of science. Thus, the need for the transition of the Russian economy to the sixth "technological order" has been determined.

Digital technologies have been implemented in various industries and in the entire economic system, which determines the development and promotion of new science-intensive technologies.

It is important to note that in spite of the ongoing activities, some industries and sectors of the economy are characterized by poorly developed infrastructures.

Within the sixth technological order, it is planned to develop all sectors of the economy. The transport industry is no exception. The urbanization and business processes require changes in the concept and tools for the development of transport infrastructure.

The sixth technological order will contribute to the creation of a powerful scientific foundation and transform it into practical results.
Within the sixth technological order, the requirements for transport communications will become stricter. These requirements concern:

- environmentally friendly consumption;

- safety;

- speed;

- energy efficiency;

- efficiency;

- comfort.

In general, the world economic system has already entered the development cycle of the sixth technological order, which affects the global modernization of the world transport system.

\section{Problem Statement}

Recently, the development of the railway infrastructure has become a crucial issue. In 2014, the government approved the investment project "Modernization of the railway infrastructure of the Baikal-Amur and Trans-Siberian railways and development of carrying capacities" [1]. The project began to be implemented in 2013 by Russian Railways,

Corresponding author: kudravera@mail.ru 
the Ministry of Transport of the Russian Federation and the Federal Agency for Railway Transport. It involves two stages. The implementation of this project was supposed to be completed in 2017.

However, the final deadline for the completion of the first stage was postponed to the end of 2020 due to the fact that the funds were not fully used. At the beginning of 2020 , only $67 \%$ of funds were disbursed.

Undoubtedly, this project is one of the largest and most important infrastructure projects in the railway industry. Therefore, it is necessary to speed up the process of commissioning of strategically important facilities. Measures aimed at accelerated modernization of the Eastern polygon are being implemented by the government. On November 12, 2019, the Chairman of the Government of the Russian Federation D.A. Medvedev gave recommendations to "update the plan for the implementation of the investment project "Modernization of the railway infrastructure of the Baikal-Amur and Trans-Siberian railways and development of carrying capacities". A detailed plan for accelerated modernization has been developed [1].

V.V. Putin said, that Russia needs a breakthrough in the development of the national transport infrastructure. Among the priorities is large-scale modernization of the BAM and Transsib. By 2025, it is necessary to increase their throughput by over 200 million tons of cargo per year.
Moreover, in the mid-2020, Russian Railways launched a new large-scale project "East. Point of attraction". It is important to note that within this project a landfill for advanced development will be created to develop the landfill, increase its competitiveness and efficiency. A railway technopolis with housing and social infrastructures, additional opportunities for training and career promotion of employees and their families will be created [2].

To implement infrastructure projects, financial resources are required.

At the same time, within the limited state budget and own funds, Russian Railways is forced to apply new funding methods. One of these is a project funding mechanism.

\section{Research Questions}

As part of the above projects, attention should be paid to the issue of project funding. Figure 1 shows the structure of funding sources for the investment project "Modernization of the railway infrastructure of the Baikal-Amur and Trans-Siberian railways and development of carrying capacities". It is clear that cofinancing is a guarantee of the execution of any project.

\section{Funding volume, billion rubles}

\section{Budget funds}

\section{Borrowed funds}

\section{Own funds of Russian railways}

\section{Resources of the National Wealth Fund}

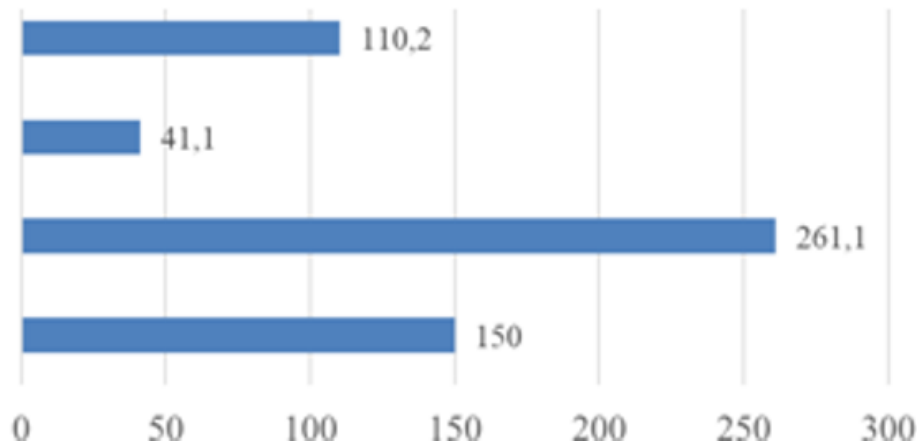

Figure 1. The structure of funding sources for the investment project "Modernization of the railway infrastructure of the Baikal-Amur and Trans-Siberian railways and development of carrying capacities"

In order for the federal projects to be implemented, a new funding method is required. That is, in order to achieve target results, it is necessary to revise the approaches to the allocation of budget funds. One of the ways to structure the project and distribute risks among all participants is to implement project funding or publicprivate partnership mechanisms. Project funding can be an alternative way to implement the project, and select an optimal combination of methods and mechanisms for attracting financial resources to the project [4]. Projects cannot be implemented using only own funds. Borrowed funds are required for funding any large project.

Since 2020, the project-funding scheme has been one of the main ways to finance the housing construction sector in Russia. At the same time, the concepts of project funding and "targeted loans" are not similar. For example, foreign project funding schemes are fullfledged investment products which are the basis for the Initial Public Offering mechanism. The project funding is effective within the investment project due to the advantageous position of fund recipients [4].

Figure 2 shows potential benefits of the projectfunding scheme.

The Russian Railways-Invest company prepared an analytical review, according to which the project funding is an innovative investment mechanism for Russian Railways. 


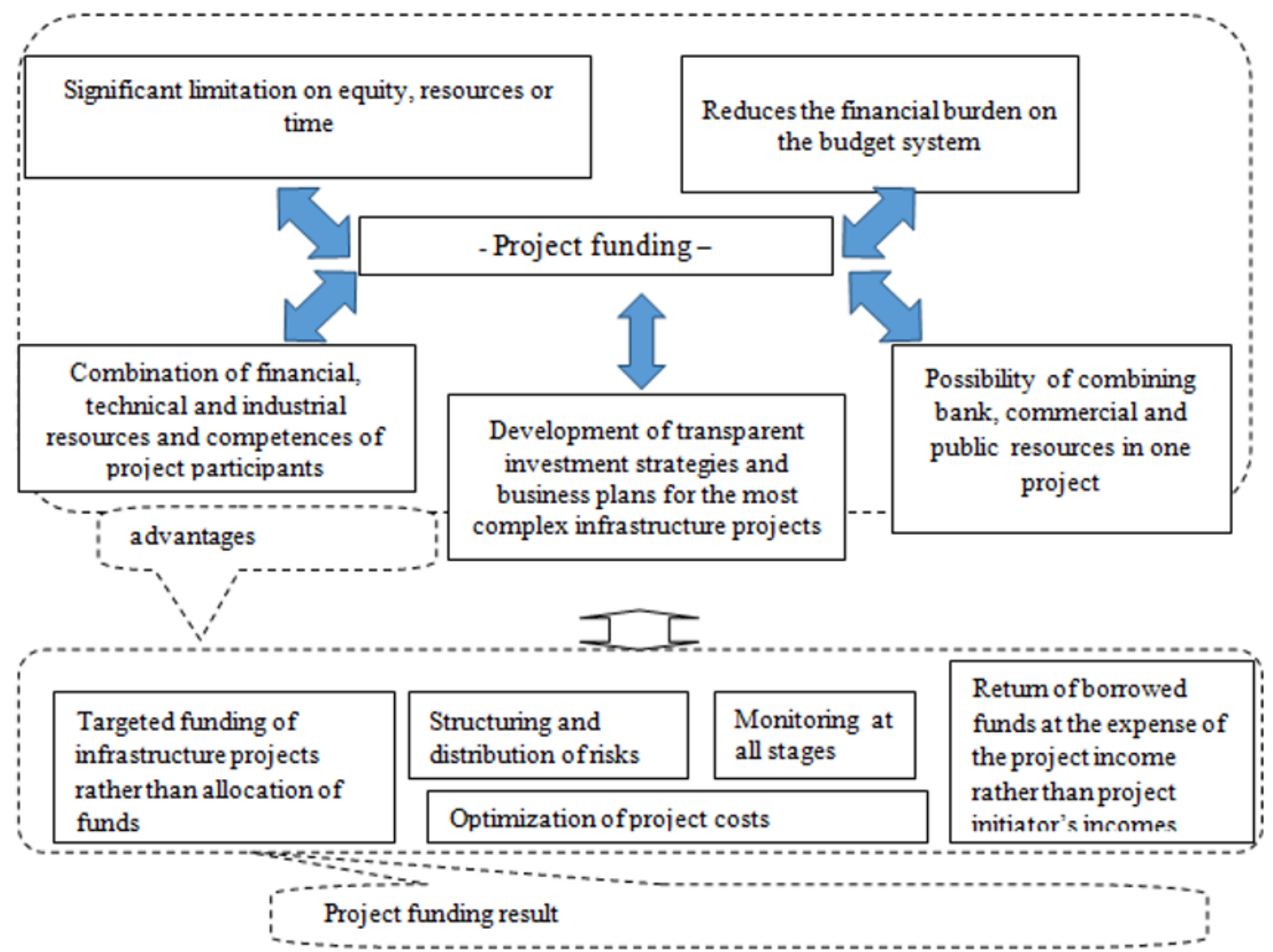

Figure 02. Project funding: advantages and result

\section{Purpose of the Study}

Currently, many industries and companies experience significant financial constraints. Russian Railways is no exception. Limited budgetary funds and own financial capabilities prevent them from choosing effective project funding mechanisms for the development of railway infrastructure.

It is necessary to create efficient high-speed transport systems. However, financial resources are required. They cannot be allocated by the government. Therefore, it is necessary to attract investment in the development of railway transport and transport infrastructures. The article aims to analyze the project-funding scheme as an alternative financial mechanism that contributes to the timely implementation of the project [3].

\section{Research Methods}

An analysis of the budget of national projects revealed that the most expensive national project is aimed at development infrastructure facilities. For its implementation, one fourth of the total amount of financial resources, equal to 25.7 trillion rubles, is required. Figure 3 shows the distribution of budget funds by industries and fields. As can be seen from Figure 3, an enormous burden falls on the budgetary system. Infrastructure projects should be funded from all types of budgets [5]. At the same time, it should be noted that budget funds cannot meet the financing needs of infrastructure projects, therefore, a mixed funding mechanism is required. Extra-budgetary resources should be used. 


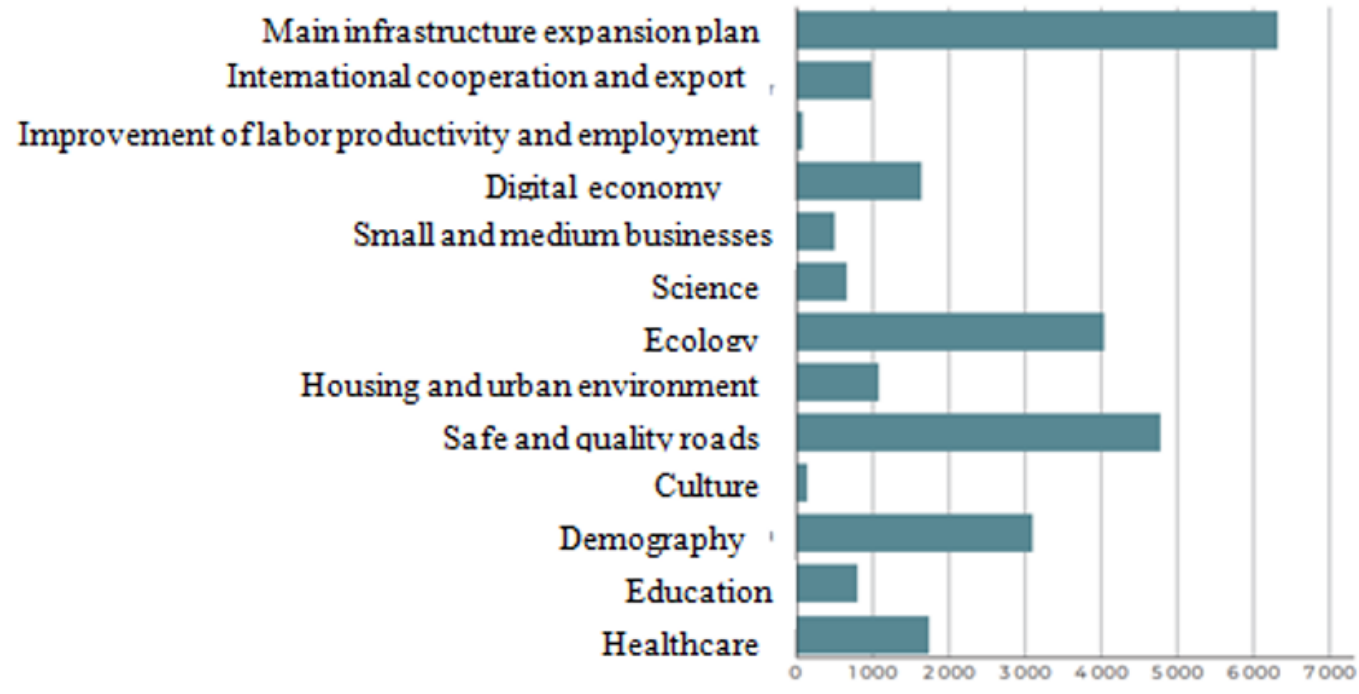

Figure 03. National project budget, billion rubles.

As can be seen from Figure 3, an enormous burden falls on the budgetary system. Infrastructure projects should be funded from all types of budgets. At the same time, it should be noted that budget funds cannot meet the financing needs of infrastructure projects; therefore, a mixed funding mechanism is required. Extra-budgetary resources should be used.

\section{Findings}

The project funding is part of business projects. It can be considered as an alternative funding method, especially when the company's investment policy is focused on raising funds from outside (Chelpanova, 2018). Sustainable development of the project funding consolidates financial resources for the implementation of infrastructure projects of Russian Railways with a significant reduction in project risks by increasing the number of project investment participants.

\section{Conclusion}

The project funding is part of business projects. It can be considered as an alternative funding method, especially when the company's investment policy is focused on raising funds from outside. Sustainable development of the project funding consolidates financial resources for the implementation of infrastructure projects of Russian Railways with a significant reduction in project risks by increasing the number of project investment participants.

\section{Acknowledgments}

The work has been published at the expense of the state task on the topic "Improving the mechanisms of interaction between polygon structures and regional corporate governance centers on the example of the Eastern railway polygon".

\section{References}

1. E.V. Bakharev. Substantiation of the effectiveness of investment project financing in railway transport. Transp. Busin. in Rus., 3, 95-97 (2016)

2. N.A. Zhuravleva, A.Yu. Panychev. Financing projects for the development of railway infrastructure: topical solutions for Russia. Econ. of railway transp., 1, 122 (2015)

3. M.A. Mova. Assessment of the economic efficiency of investment projects of JSC "Russian Railways". Socio-econ. probl., 1, 175 (2013)

4. S.E. Prokofiev, V.I. Murar, I.V. Rashkeeva, M.V.Elesina. Project financing: nature and significance Sci., 6, 1 (2014)

5. I. Grigorovich, M. Eliseev, P. Seregin. Kilometers. Projects. Money. Analysis of the prospects for the development of project financing instruments (JSC IC RZD Invest, Moscow, 2019)

6. M.B. Chelpanova. Problems of efficiency of investment in railway infrastructure (2018). Retrieved from: https://www.hse.ru/data/2018/ 05/31/1149339027_final.pdf 